\section{Nuclear Merger}

In contrast with the United States and West Germany, Britain has not been a successful exporter of nuclear instruments and equipment. The Parliamentary Select Committee on Science and Technology has explained the poor export performance of British nucleonic firms by the fact that most of them were small, and centred scientifically as well as geographically about Atomic Energy Authority establishments, so that some of them have no customers apart from the authority, and many have no research departments.

The recent merger of three of the largest nucleonics firms, Nuclear Enter prises (GB), and the nucleonics subsidiaries of EMI and Elliott-Automation, so as to create a $£ 2 m$ company, is an important event for the industry. The Industrial Reorganization Corporation supplied Nuclear Enterprises with $£ 600,000$ for the take over, all the more willingly, no doubt, because FilliottAutomation had been negotiating the sale of its subsidiary with the American company, Teledyne. The factories of the enlarged Nuclear Enterpriscs will be at Edinburgh and near Aldermaston, the EMI staff moving from their present sites at Hayes and Wells.

Nuclear Entcrprises itself concentrated on the manufacture of instruments such as radiation detectors, gamma-ray camcras, and automatic radioactive sample changers used in research in hospitals, universities and industry. To this range will now be added the health physics equipment, notably hand and foot monitors, and data processing machinery produced by EMI, as well as the extensive contribution of industrial analytic and gauging equipment from Elliott-Automation. Most important, the new Nuclear Enterprises will be able to offer two British made multi-channel analysers, where it previously only acted as import agent for Italian machincs.

It is claimed that the new firm will be the biggest of its kind in Europe, but, as so often in the industry of advanced technology, this only means that the company compares with a medium-sized American firm. Nuclear Chicago, to give an indication of American scale, sells $\$ 23 \mathrm{~m}$ worth of instruments each year, exporting 20 per cent of its output--more than $\$ 750,000$ - to Britain alone; the top six British firms have a combined turnover of about three million pounds.

The amalgamation of three of Britain's biggest manufacturers of nucleonics may encourage similar association among some of the other three or four bigger firms and subsidiaries. But if and when the big can be persuaded to become bigger, there will still be the problem of how to encourage export and research activity among the forty or so smaller nucleonic firms within the satrapies of the various AEA establishments.

\section{Trade in Technology}

WITHIN the next month or so, the Ministry of Teehnology is hoping to sign a new technological agreement with the Sovict Union. Mr Anthony Wedgwood Benn, the minister, is particularly keen about the agreement. "It will pave the way for closer contact between Britain and the Soviet Union in the future. Each has a great deal to gain from an exchange of information in the fields of forward research, industrial technology and planning techniques." But Mr Benn thinks that the greatest gains will come from the development of international systems for the exchange of scientific and technological information by means of a world information retrieval and dissemination system.

Similar agreements have already been signed by the United Kingdom with Poland and Hungary and, if they are anything to go by, the Anglo-Soviet agreement is likely to be a pretty innocuous document. But this need not matter very much. The first reaction from industrialists was that with agreements of this sort, what they say is often less important than the cordial relations they foster. The Confederation of British Industry is enthusiastic about the agreement. "The important thing is not the pious statements of intent, but the fact that there is a determination to make the agreements work," one CBI official said. The CBI sent a mission to the Soviet Union recently, and has been surprised how quickly the benefits have been showing themselves. It has also been surprised at the wide range of projects on which the Russians were eager to collaborate-instead of searching around for points of contact, the mission found it was easier to add up the number of things in which the Russians were not interested. Eight particular areas of interest emerged from the CBI mission-clectricity supply and generation, heavy generating plant, the motor industry, the metallurgical industry, industrial pollution, patents, the railway system with particular emphasis on contriners, and standards. Some of these subjects may be mentioned in the agreement when it is signed; other possible subjects are coal mining machinery, computers and electronics, and chemicals and chemical plants. It is also thought that the Russians may be interested in civil aviation technology. This is a field where Russian designs would be unlikely to sell on a world market, even if there were no political barriers. For one thing, the period between engine overhauls in Russian civil aircraft has tended to be much too short for airline economics.

Some of the bigger British firms already have a foot in the door. Imperial Chemical Industries, for instance, has negotiated its own agreement with Russia, after Sir Paul Chambers met Mr A. Kosygin in 1964. The agreement, signed in October 1966, provides for collahoration in plastics, petrochemicals and synthetic fibres. And British Motor Holdings, while admitting that the new agreement would "obviously be very useful", says that it has already submitted plans for a complete car plant to build two BMC models, the 1100 and 1800 , in the Soviet Union. A team of BMC enginecrs will be going to Russia next month to hold discussions, principally about engines, automatic transmissions and suspension systems. Leyland and Courtaulds are two other British companics which have shown interest in the Russian market, and Leyland has put forward plans for a complete factory to build commercial vehicles in Russia. English Electrie has sold a number of computers to Eastern Europe, most rocently a System 4 computer to Russia.

But what of Mr Benn's ambitious schemes for an international data storage and retrieval system? So far the Soriet Union has shown interest in only one such proposal, put forward by the International Atomie Fnergy Agency. This is a development of the scheme now in operation for sharing nuclear crossscetions internationally, and would provide an inter- 
national nuclear information service based on Vienna. The proposal has been widely discussed over the past few years, but has not yet been finally agreed. The Soviet Union does have its own information retrieval system, called Viniti, and has done some fundamental studies of language and mechanization. But it is not clear exactly what stage the Russian system has reached. Mr John Grey, of the British Office of Scientific and Technical Information, says that to produce an effective international system it would be necessary to produce standard formats and procedures, as well as compatible indexing systems and programmes. With the third generation of computers, he hopes that this will be very much easier, but he stresses that all systems are still experimental and that the next two or three years are likely to be of crucial importance for international collaboration. "There can't be too much discussion on it," he said.

\section{Culham Divided}

IT now seems probable that the Science Research Council will be taking over responsibility for at least part of Culham Laboratory. Dr Robert Wilson, who is director of the group at Culham working on astrophysics, says that "agreement has been reached in principle" for the phased take-over of his group by the SRC. But he emphasizes that consultations are by no means complete, and there are a number of questions connected with the staff which still have to be settled. If the transfer can be made, it will do something to restore optimism at Culham-since the Minister of Technology, Mr Anthony Wedgwood Benn, announced in July the decision to cut the laboratory's expenditure by 10 per cent a year for five years, there has been something of an air of gloom. Because the astrophysical work was supported from the fusion budget, it was as vulnerable as any other project at the laboratory.

If the discussions go well, the astrophysical group will be converted to an SRC unit based at Culham. This process should be complete by April 1969, and the group will remain at Culham at least until 1971. The group consists of 18 professionals and 10 others, and the annual budget has been running at something like f0.25 million a year. (This is not a hard and fast figure, because it includes overheads and some laboratory plasma work which the SRC may not take over. The exact financial commitment of the SRC will not be clear until the negotiations are complete.) As well as studying the solar spectrum with stabilized Skylark rockets, the group has been responsible for the measurement of new spectral lines and of atomic cross-sections. It now hopes to move on to stellar spectroscopy, with rockets stabilized on stars.

So far, nothing has been decided about the team which is working on the design of a large astronomical telescope for ESRO. This is a different team, consisting of 25-30 professionals working part time. As yet, the decision is not urgent, because ESRO has not decided whether to proceed with the project. If the LAS project does proceed, Dr Wilson says, the position of the team working on the design will have to be considered.

There is little doubt that the move to the SRC will make for better co-ordination of the British space research programme, but there is no particular reason to believe that money will then be easier to come by. The programme will have to find its own level within the competitive atmosphere of the SRC. As a number of commentators-Nature among them-have suggested, a move to the SRC might be the answer for the whole of the Culham establishment. But there has so far been no hint of that.

\section{Facing the Future with $\mathrm{SI}$}

A CONFERENCE of editors of British scientific journals adopted on December 11 a recommendation that editors should collectively encourage the use in scientific journals of the system of metric units known as SI (which is an abbreviation for Système International d'Unités). A document prepared during the past six months by a working party under Professor James Lighthill has produced a detailed list of definitions and suggestions including, in particular, the view that "the journals devoted to science and engineering should seize the opportunity of playing a crucial role in helping to end the confusion and wastefulness (both mental and material) resulting from the present multiplicity of units". This decision has been given the encouragement and the blessing of the Ministry of Technology, which is now hoping for more or less complete metrification of the British system of weights and measures by the mid-seventies.

The basic units of the SI system are the metre $(\mathrm{m})$, kilogramme (kg), second (s), ampere (A), degree Kelvin $\left({ }^{\circ} \mathrm{K}\right)$ and candela (cd). Allowable derivatives include the Joule $(J)$ but not the calorie, the weber $(\mathrm{Wb})$ but not the Gauss, the hertz $(\mathrm{Hz})$ but not the cycle per second and the degree Celsius $\left({ }^{\circ} \mathrm{C}\right)$ but not the degree Centigrade (which is said to be one of the points on which French delegates to the international conferences have placed a great deal of emphasis). One of the characteristics of the SI system is that fractions and multiples of units should wherever possible be quoted to the nearest integral or fractional multiple of a thousand, which means that the Angstrom $\left(10^{-10} \mathrm{~m}\right)$ is banned and even the centimetre $\left(10^{-2}\right)$ is frowned on. Needless to say, the foot, the pound, the gallon and the Btu have nothing said in their defence.

By all accounts, a great many British journals have already agreed to regard 1968 as a period of experiment and of transition. Although the document produced by the working party (see Nature next week for further details) seems to have obtained a sympathetic reception, it remains to be seen how many journals will follow Professor Lighthill's suggestion that they should, after a suitable warning period, automatically return manuscripts in units other than SI.

\section{ELDO Fails Again

$$
\text { from Angela Croome }
$$

Aцтночян the political crises for co-operative European space enterprises took place in 1966, the technological failures which give a gloss of justification to the political wrangling have occurred this year. There were the pre-launch troubles with the first ESRO (European Space Research Organization) satellite in the spring which have made necessary a year's postponement in the launching of the backup vehicle and considerable extra cost. Now the two ELDO shots of the 